\title{
Ortaokul Öğrencilerinin Okula Devamsizlik Nedenleri (Söke İlçesi Örneği)
}

\author{
Vural HOŞGÖRÜR \\ Muğla Sttkı Koçman Üniversitesi Ĕgitim Fakültesi, \\ vuralhosgorur@mu.edu.tr \\ Mustafa POLAT \\ Öğretmen, Aydın İl Milli Eğitim Müdürlü̆ğü, \\ polatmustafa09@hotmail.com
}

\begin{abstract}
$\ddot{O ̈ z e t}$
Ortaokullarda öğrenim görmekte olan devamsiz ögrencilerin devamsizllk nedenlerinin ortaya çıkarılmasını amaçlayan bu araştırmada nitel araştırma desenlerinden olgu bilim (fenomonolojik yaklaşım) kullanilmıştır. Araş̧ırmanın çalışma grubunu; Aydın ili Söke ilçesinde 2013-2014 öğretim yılı içerisinde 20 gün ve üzerinde devamsızlık yapan ögrenci saylsı en fazla olan ortaokul oluşturmuştur. Araştırma kapsamında olan bu ortaokul amaçlı örnekleme yöntemlerinden biri olan aykırı durum örneklemesi ile seçilmiştir. Bu okulda devamsızlık yapan ögrencilerin tamamı çalışmaya dahil edilmek istenmiş ancak araştırmaya gönüllü olarak 27 ögrenci katılmış ve doğal olarak bu grup araştırmanın çalışma grubunu oluşturmuştur.

Araştırmada; veri toplamak için araştırmacı tarafindan hazırlanan veri toplama aracı kullanılmıștır. Veri toplama aracı uygulama öncesi uygulama yapılacak okulda devamsılık yapan iki ögrenciye uygulanmiştır. Onlardan alınan dönütler sonucu araştırma tarafindan veri toplama aracına son şekli verilmiştir. Veri toplama aracı araştırmacılar tarafindan devamsızlık yapan öğrencilere yüz yüze görüşerek uygulanmıştır. Çalışma grubundan elde edilen veriler nitel araştırma analiz teknikleri ile incelenmiştir. Elde edilen veriler tema ve alt temalara ayrllmış; frekans ve yüzdelerine de bakllarak değerlendirilmiştir. Araştırma sonucunda devamsızlık yapan ögrencilerin; devamsızlık nedenlerinin başında ailevi nedenlerin geldiği bunu sırası ile kişisel, sağlık ve arkadaş çevresi kaynaklı nedenlerin izlediği tespit edilmiştir.
\end{abstract}

Anahtar Kelimeler: ortaokul, öğrenci, devamsızlık, devamsızlık nedenleri

\section{Reasons For Absence Of Middle School Students (The Sample Of Söke Province)}

\begin{abstract}
Students who are studying in secondary schools staple causes of absenteeism in this study aimed at uncovering cases of qualitative research design science (phenomenological approach) is used. The study group; In Aydin 20 days in a school year, and with the greatest number of students who are absent on the middle school and secondary school formed in the town of Aydin's Soke in 2013-2014 academic year that have been identified. This part of the study, one of the secondary infractions purposive sampling method
\end{abstract}


was selected by sampling. All students in this school truants were asked to be included in the study but 27 students participated in the study voluntarily and naturally this group formed the study group

In the study; data collection tool to collect data prepared by the researcher was used. Data collection tool to be applied before the application was applied two students at the school who have absenteeism. They are the result of feedback received from the survey is finalized by the data collection tool. Data collection tool by researchers truants were administered face to face consultation. The data obtained from the study group were examined by qualitative research analysis techniques. The resulting data divided into themes and sub-themes; was assessed by using frequency and percentage of the data.

Students who are absent as a result of research; the leading cause of absenteeism as it comes with a personal family reasons, health and the environment originating from a friend of the reasons that follow have been identified. In this study, the findings and the recommendations made research was delivered to the county's district national education directorates.

Keywords: Secondary school, students, absenteeism, causes of absenteeism

\section{Giriș}

Okula devamsızlık, fiziksel, psikolojik ve toplumsal birçok etmenden kaynaklanabilen ve öğrencinin akademik başarısını olumsuz yönde etkileyebileceği düşünülen istenmeyen bir öğrenci davranışıdır (Altınkurt, 2008). 7 Eylül 2013 günü 28758 sayılı Resmî Gazete'de yayınlanan Millî Eğitim Bakanlığı Ortaöğretim Kurumları Yönetmeliği'nin 36. maddesi, devam-devamsızlık durumunu düzenlemektedir. Buna göre; "Okula devam zorunludur. Veliler, öğrencilerinin okula devamını sağlamakla yükümlüdürler. Millî Eğitim Temel Kanunu'nun 26. Maddesi gereğince okul yöneticileri, millî eğitim müdürleri ve mahalli mülkî idare amirleri öğrencilerin okula kayıt ve devamıyla ilgili gerekli tedbirleri alırlar." Yine bu yönetmeliğe göre devamsızlık nedeniyle başarısız sayılan ve öğrenim hakkı bulunan öğrenciler takip eden öğretim yılında okula devam ettirilir. Sınıf tekrarı hakkı bulunmayanların okulla ilişikleri kesilerek Açık Öğretim Lisesi veya Mesleki Açık Öğretim Lisesine gönderilmektedir.

Devamsızlık yapmanın tek bir nedeni yoktur. Devamsızlık probleminin ortaya çıkmasında ve bu problemin devam etmesinde birçok faktör birlikte rol oynayabilir. Bu faktörler arasında; toplum desteğinden yoksun olma, destekleyici olmayan bir okul ortamı, aile yaşantısının düzgün olmaması, kötü hava şartları ve ulaşım problemleri, sağlık problemleri ve kişisel yetersizlikler bulunabilmektedir. (Teasley'den aktaran Öztekin, 2013). Devamsızlık yapan öğrenciler kısa vadede eğitimleriyle ilgili birçok sorunla karşılaşabilmekte, akademik olarak ciddi problemler yaşayabilmektedirler. Okula yüksek devamsızlık nedeni ile derslerde zorlanan ve akademik olarak geri kalan öğrencilerin okulu terk riski artmaktadır. Düşük notlar ve başarısız sınav sonuçları, müfredat dışı aktivitelere katılımın azlığı, istenmeyen sınıf içi davranışlar, öğretmen ve arkadaşlarla olumsuz ilişkiler mezuniyet olasılığını azaltmaktadır (Jerald, 2006).

$\mathrm{Bu}$ araştırmada, öğrencinin devamsızlık yapmasına neden olan etmenler yapılan literatür incelemesinden sonra beş boyutta ele alınmıştır. Bunlar; öğrenci kaynaklı nedenler, aile kaynaklı nedenler, öğretmen kaynaklı nedenler, okul ve okul yöneticisi kaynaklı nedenler, arkadaş çevresi kaynaklı nedenlerdir. Araştırmada devamsızlık türleriyle ilgili bir ayrıma gidilmemiştir. Kullanılan devamsızlık kavramı Milli Eğitim Bakanlığı'nın ilköğretim kurumlarının sınıf geçme ve sınavlarla ilgili yayınlamış olduğu yönetmelikte (MEB 2006) belirtilen kaza, ölüm, doğal afet, tutuklanma, göz 
altına alınma gibi nedenler dışında geçerli olmayan herhangi bir nedenle öğrencinin derse girmemesini ya da okula gelmemesini ifade etmektedir.

\section{Problem Durumu}

Okullarda gerçekleştirilen örgün öğretim faaliyetlerinin gereklerinin yerine getirilebilmesinin en önemli şartlarından birisi öğrencilerin okula erişim ve devamlarının sağlanmasıdır. Son yıllarda öğrenci devamsızlığı okullardaki en büyük sorunlardan biri haline gelmiştir. Türkiye'de son yıllarda okullulaşma oranında artış görülse de 20 günün üzerinde özürsüz devamsızlık oranı kızlarda \% 2,9'dan \% 4,2'ye, erkekler de ise \% 3,5'ten \% 4,4'e yükselmiştir. (ERG, 2010).

OECD (2013), tarafından PISA verilerinden yararlanılarak derse geç kalan ve derse devamsızlık yapan öğrenciler üzerine yapılan bir çalışmada, PISA 2012 verilerine göre, PISA uygulamasından önceki iki hafta boyunca OECD ülkeleri ortalamasına göre en az bir dersi kaçıran öğrencilerin oranı \%18 iken, Türkiye'de ise bu oran \%45 dir. PISA 2003 sonuçları (OECD 2004), 2012 sonuçları ile karşılaştırıldığında, geçen süre zarfın da OECD ülkeleri ortalamasında kaçırılan ders oranında \% 12'lik bir iyileşme söz konusu iken Türkiye'de herhangi bir iyileşme gözlenmemektedir. 2012 PISA uygulamasından önceki iki hafta boyunca, en az bir defa tüm gün okula gitmeyen öğrenci oranlarına bakıldığında, bu oran Türkiye'de \%54 iken, OECD ülkelerinde ise sadece \%14 dür (OECD 2013).

Bu sonuçlar öğrencilerin okula devamsızlık davranışlarının ve arkasındaki nedenlerin daha detaylı araştırmalar ve analizler ile incelenmesini gerektirmektedir. Devamsızlığın yüksek olmasının nedenlerinin sosyal yüklemelerden, öğrencilerin bireysel tercihlerine kadar birçok değişken kullanılarak analiz edilip tartışılması gerekmektedir. Okul yönetimlerinin görevlerinden biri de öğrencilerin okula devamlılığını sağlamaktır. Bunun için öğrencilerin devamsızlık yapmasına neden olan etkenlerin bilinmesi önemlidir. Öğrencilerin okula devamsızlık nedenleri ortaya çıkarılıp gerekli analizler yapıldıktan sonra eyleme geçilip gerçekçi ve özel önlemler alınabilir. "İlgili literatür incelendiği zaman uluslararası alanda öğrenci devamsızlığ üzerinde yapılmış birçok araştırma olduğu ancak, ulusal alanda ilköğretim ve ortaöğretim kurumlarında öğrenim gören öğrencilerin devamsızlık nedenlerinin belirlenmesi ve devamsızlığın önlenmesine yönelik sınırlı sayıda araştırma olduğu görülmüştür." (Kadı, 2000; Pehlivan, 2006; Altınkurt, 2008; Özbaş, 2010; Yıldız, 2011; Şimşek, 2011; Öztekin, 2013.). Ciddi bir sorun haline gelen ve olumsuz sonuçlar doğuran devamsızlık alışkanlığının nedenlerinin akademik anlamda araştırılması önem taşımaktadır.

$\mathrm{Bu}$ çalışmanın amacı ortaokul öğrencilerinin okula devamsızlık nedenlerini ortaya çıkarmak olup, bu amaca dayalı olarak aşağıda belirtilen alt problemlere yanıt aranmaya çalışılmıştır. Okul devamsızlıklarının; Aile, Öğrenci, Okul ve Okul yöneticisi, Öğretmen ve Arkadaş çevresi kaynaklı, nedenleri nelerdir?

\section{YÖNTEM}

\subsection{Araștırmanın Modeli}

Araştırmada; öğrencilerin devamsızlık nedenlerinin derinlemesine incelenmesi amacıyla nitel 
araştırma desenlerinden olgu bilim (fenomonolojik yaklaşım) yaklaşımı kullanılmıştır. Buradaki amaç, devamsızlığın neden yapıldığını keşfetmeye çalışmaktır. Bu amaçla araştırmacılar tarafindan hazırlanan bir görüşme formu kullanılarak 20 günden fazla devamsızlık problemi olan öğrencilerle yüz yüze görüşmeler yapılarak devamsızlık nedenleri derinlemesine incelenmeye çalışılmıştır.

\section{2. Çalışma Grubu}

Bölgede tarımsal faaliyetlerin yanında sanayinin de mevcut olması, mevsimlik işçilerin yoğun olması ve göç alan illerimizden biri olması gibi nedenler ile çalışmanın Aydın ilinde gerçekleştirilmesine karar verilmiştir. Aydın ilinde 2013-2014 öğretim y1lı içerisinde 20 gün ve üzerinde devamsızlık yapan öğrencisi sayısı fazla olan ortaokullar araştırılmış Aydın ilinin Efeler, İncirliova, Ortaklar, Germencik ve Söke ilçelerinde öğrencilerinde devam sorunu yaşayan toplam 12 okul tespit edilmiştir. Bu ilçelerdeki okullar içinden Söke ilçesi Bağarası beldesi Hürriyet ortaokulu çalışmanın yapılacağı okul olarak seçilmiştir. Bu okulun seçilmesinde; beldenin Aydın ilinin yukarıda bahsedilen özelliklerini genel olarak taşıması, öğrencilerin ailelerinin tarım işlerinde ve mevsimlik işlerde geçici olarak çalışan kimselerden olması, okulun öğrencilerinin sosyo ekonomik bakımdan dezavantajlı ailelerin çocuklarından oluşması, 20 gün ve üzeri devamsızlık yapan öğrenci sayısının çok olması ve araştırmacıların çevreyi ve bölge insanını iyi tanımaları gibi durumlar etkili olmuştur. Amaçlı örnekleme yöntemlerinden biri olan aykırı durum örneklemesine uygun olarak seçilen bu okuldaki devamsızlık yapan öğrencilerin tamamı (51 öğrenci) çalışmaya dahil edilmek istenmiş ancak öğrencilerden 27'si bu araştırmaya gönüllü olarak katılmayı kabul etmiştir.

\subsection{Veri Toplama Aracı ve Verilerin Analizi}

Önemli düzeyde devamsızlığa sahip öğrencilerin okul devamsızlıklarının nedenlerinin araştırıldığı bu çalışmanın veri toplama aracı; daha önce Pehlivan (2006) tarafindan hazırlanmış ve uygulanmış bir veri toplama aracından da yararlanılarak, araştırmacılar tarafından bir öğretim üyesi, bir müdür yardımcısı ve bir okul rehber öğretmeni yardımıyla yeniden düzenlenip çalışma ve koşullara uygun hale getirilen yarı yapılandırılmış görüşme formu ile elde edilmiştir. Soru formu gerçek uygulamada kullanılmadan önce bir ön uygulama yapılarak devamsızlıkları çok olan iki öğrenciye uygulanmıştır. Öğrencilerin verdikleri yanıtlar ve alınan bilgiler çerçevesinde görüşme formuna son şekli verilerek gerçek uygulama yapılmıştır. Uygulama sırasında öğrenci görüşme formunun cevaplandırma süresinin yaklaşık $10-15$ dakika sürdüğü gözlenmiştir. Öğrencilerle yapılan görüşmeler sürecinde elde edilen veriler, betimsel ve içerik analiz teknikleri kullanılarak çözümlenmiş, analiz edilen veriler üzerinden kodlamalar yapılarak temalar ve alt temalar oluşturulup, bu temalar ve alt temalar altında yorumlara yer verilmiştir.

\section{BULGULAR VE YORUM}

\subsection{Kişisel bilgiler}

Araştırmaya katılan öğrencilerin 8’i (\% 29,7) kız, 19’u (\%70,3) erkektir. Devamsızlık yapan 2 öğrenci $(\%$ 7,4) 11 yaşında, 5 öğrenci (\% 18,6) 12 yaşında, 4 öğrenci $(\%$ 14,8) 13 yaşında, 9 öğrenci $(\% 33,3) 14$ yaşında, 4 öğrenci $(\% 14,8) \quad 15$ yaşında ve 3 öğrenci $(\% 11,1) \quad 16$ yaşındadır. Çalışma grubunun cinsiyet dağılımına bakıldığında erkek öğrencilerin kız öğrencilerden daha fazla devamsızlık yaptıkları söylenebilir. Öğrenci devamsızlığı ile ilgili olarak, Türkiye'de Kadı (2000), tarafından 
yapılan bir araştırmada "devamsızlık nedenlerinden biri olarak; erkek çocukların işgücünden faydalanılması ve aileye gelir getirmesi için çalıştırılıyor olması" bulgusuna ulaşılmıştır. Devamsızlık yapan öğrencilerden birinin 5. sınıf, sekizinin 6. sınıf, altısının 7. sınıf ve on ikisinin 8. sınıf öğrencisi olduğu, devamsızlığın en yoğun olarak 8. Sınıfta yapıldığı anlaşılmaktadır. Devamsızlığ 1 en çok 14 yaş grubundaki öğrenciler yapmaktadır. Ergenlik çağında olan bu yaş grubundaki öğrencilerin ilgilerinin okul dışına kaydığı, bağımsızlık kazanma çabalarının fazla olduğu ve otorite olarak görülen anne, baba ve öğretmenlere karşı gelmenin arkadaş gruplarınca desteklendiği bu gibi nedenlerin devamsızlığı arttırdığı söylenebilir. Ortaöğretimin ilk yılları kız öğrencilerin ve erkek öğrencilerin ergenlik dönemlerinin başlangıç yılları olması nedeniyle önemlidir (Kalafat, 2007).

\section{2. İşte çalışma durumu}

Öğrencilerin eğitim ve öğretim dönemi içerisinde herhangi bir işte çalışma durumu incelendiğinde. 11 öğrenci $(\%$ 40,7) herhangi bir işte çalışmadıklarını ifade etmekle birlikte görüşme derinleştikçe, herhangi bir işte çalışmadıklarını söyleyen öğrencilerden bazılarının evde kardeşlerine baktıkları, bazılarının anne ve babasının birlikte işe gitmesi nedeniyle ev işlerini yapmak zorunda kaldıkları anlaşılmıştır. Araştırmaya katılan öğrencilerden 16'sı (\% 59,3) ise bir işte çalıştıklarını söylemişlerdir. $\mathrm{Bu}$ öğrencilerin çalıştıkları işler düzenli işler olmayıp çoğunlukla mevsimlik işler şeklindedir. Ekonomik sıkıntı içinde bulunan ailelerin çocuklarını okula göndermek yerine tarla, bağ, bahçe işlerine gönderdikleri anlaşılmıştır. Bu gruptaki öğrencilerden bazılarının verdikleri yanıtlar aşağıda gösterilmiştir.

Öğrenci 5: Ailemle beraber çalışıyorum. Devamsızlığımı etkiliyor (6. Sinıf, Erkek).

Öğrenci 10: Ovada çapa, sulama ve hayvan baktığım durumlar oluyor okula gidemiyorum. (7. Sinıf, Kız).

Öğrenci 12: Çapa yapmak, pamuk toplamak gibi işlerde çalışıyorum. Derslere devamsiz oluyorum (7. Sinıf, Kiz).

Öğrenci 14: Beyaz eşya tamircisinde çalışıyorum. Çalışmadığım zamanlar okula gidebiliyorum (7. Sinıf, Erkek).

"Bazı araştırma sonuçlarına göre, sosyo ekonomik durumu iyi olmayan ailelerden gelen öğrencilerin daha fazla devamsızlık yaptıkları anlaşılmaktadır." ( Öztekin, 2013). "Ailenin çocuğun okul yaşantılarına ilişkin ihtiyaçlarını karşılayamaması ve ekonomik gerekçelerle çocuğun işgücüne ihtiyaç duyması da bir diğer devamsızlık nedenidir." (Kadı, 2000; Özbaş, 2010). Ancak, OECD tarafindan PISA sonuçlarına dayalı olarak devamsızlık yapan öğrencilerin durumlarının sosyo ekonomik (avantaj-dezavantaj) bakımdan değerlendirilmesinde, yukarıdaki araştırma bulgularının tersine OECD ülkelerinden farklı olarak Türkiye'de avantajlı öğrencilerin devamsızlık yapma durumlarının daha yüksek olduğu ifade edilmektedir. (OECD. 2013).

\subsection{Aile durumu}

Devamsız olan öğrencilerin kardeş sayıları değerlendirildiğinde; 2 öğrencinin $(\% 7,4)$ ailede tek çocuk olduğu, 2 öğrencinin ( \% 7,4) 2 kardeşi olduğu ve 23 öğrencinin $(\% 85,2)$ ise 3 ve üzerinde sayıda kardeşe sahip olduğu görülmektedir (Bu 23 öğrencinin 6'sının 3, 5'inin 4, 4'ünün 5, 2'sinin 6, 3'ünün 7 ve 3 'ünün 8 kardeşi vardır). Bu veriden hareketle 3 ve daha fazla kardeş olan öğrencilerin devamsızlık oranlarının, 2 ve 1 kardeş olan öğrencilerden daha yükssek olduğu görülmektedir. Öztekin 
(2013), yaptığı çalışmada devamsızlık yapan öğrencilerin çoğunun çok çocuklu kalabalık bir evde yaşadıklarını ifade etmiştir."

Araştırma bulgularına göre 25 öğrencinin $(\% 92,6)$ anne ve babasının sağ olduğu ve 2 öğrencinin $(\% 7,4)$ babasının vefat etmiş olduğu anlaşılmıştır. Öğrencilerden 2 'sinin ebeveynlerinden birisi vefat ettiği için anne - baba birlikteliği olmadığı, 22 öğrencinin anne ve baba birlikteliğine sahip olduğu, 3 öğrencinin anne ve babasının ayrı olduğu anlaşılmıştır. Devamsızlık yapan öğrencilerin ( \% 81,5) 'nin anne ve baba birlikteliğinin bulunduğu, (\% 18,5) 'nin anne ve baba birlikteliğinin bulunmadığ tespit edilmiştir. Bu verilerden hareketle anne ve baba birlikteliğinin okula devamsızlık konusunda bir engel oluşturmadığı söylenebilir.

\begin{tabular}{llcc}
\multicolumn{3}{c}{ Çizelge 1. Annenin Eğitim Durumu. } & \\
\hline & Faktörler & N & \% \\
\hline \multirow{3}{*}{ Anne eğitimi } & Okuryazar Değil & 14 & 51,9 \\
& İlkokul & 11 & 40,7 \\
& Ortaokul & 1 & 3,7 \\
& Lise & 1 & 3,7 \\
& Toplam & 27 & 100 \\
\hline
\end{tabular}

Çizelge 1'e göre 14 öğrencinin annesi okuryazar değildir. 11 öğrencinin annesi ilkokul mezunudur. 2 ögrencinin annesi ortaokul mezunu ve 1 öğrencinin annesi lise mezunudur. Bu verilere göre devamsızlık yapan öğrencilerin \% 92,6 sinin annelerinin eğitimlerinin çok yetersiz olduğu ortaya çıkmıştır. Annelerin eğitim bakımından dezavantajlı durumunun, öğrencilerin devamsızlık yapmasında ve devamsızlık yapan öğrencilerin okula devam etmelerini sağlayamama bakımından olumsuz bir durum oluşturduğu söylenebilir. Senemoğlu (2005)'na göre, “Öğrencinin aile ortamı, onun davranışlarının temel kaynağıdır. Anne babanın çocuk yetiştirme tarzları, eğitim düzeyleri, öğrenci davranışlarını ve okula devam durumlarını etkilemektedir."

Aşağıdaki çizelge 2'ye göre devamsızlık yapan 12 öğrencinin babası okuryazar değil, 10 öğrencinin babası ilkokul, 3 öğrencinin babası ortaokul, 1 öğrencinin babası lise mezunudur. $\mathrm{Bu}$ verilere göre devamsızlık yapan öğrencilerin \% 81,4'nün babalarının eğitimlerinin çok yetersiz olduğu ortaya çıkmıştır.

Çizelge 2. Babanın Eğitim Durumu

\begin{tabular}{llcc}
\hline & Faktörler & N & \% \\
\hline \multirow{2}{*}{ Baba eğitimi } & Okuryazar Değil & 12 & 44,4 \\
& İlkokul & 10 & 37
\end{tabular}




\begin{tabular}{llcc}
\hline \hline & Ortaokul & 3 & 11,1 \\
& Lise & 2 & 7,5 \\
Toplam & 27 & 100 \\
\hline
\end{tabular}

Gökşen ve arkadaşları (2009), okulu terk açısından annenin eğitim düzeyinin babaya kıyasla daha belirleyici bir etmen olduğunu ortaya koymuşlardır. Okula devam eden çocukların \% 62'sinin annesi okur yazar iken, okulu terk eden çocukların \% 83,5'inin annesi eğitimsizdir. Bakış ve arkadaşları (2009)'da yaptıkları araştırma ile annenin eğitiminin kız çocukların okullulaşması üzerinde önemli bir etkisi olduğunu, fakat erkek çocuklar üzerinde anlamlı bir etkisi olmadığını ortaya koymuşlardır. Araştırma verilerine göre öğrencilerin babalarının, öğrencilerin annelerinden daha eğitimli olduğu anlaşılmıştır. Buna karşın babaların çalışması ve çocuklarının eğitimiyle annelerin daha yakından ilgilenmek durumunda kalması nedeni ile ilgilenmesi, babaların annelerden daha eğitimli olmasının öğrencilerin devamsızlık probleminin çözümünde olumlu bir rol oynamasına engel teşkil ettiği söylenebilir.

\subsection{Okulda başarı durumu}

Elde edilen bulgulara göre araştırmaya katılan devamsız öğrencilerin 16’sı $(\% 59,2)$ kendini başarısız olarak, 11'i $(\% 40,8)$ ise kendini başarılı bir öğrenci olarak görmektedir.

a) Kendini başarısız olarak niteleme: Öğrencilerin sınavlardan aldıkları notların kötü olması, okulu sevmemeleri, dersleri yapamayacaklarına ilişkin inançları, bir işte çalışıyor olmaları, kendilerini başarısız hissetmelerine neden olmaktadır denilebilir. Kendini başarısız ve yetersiz olarak gören öğrencilerin okula devam ile ilgili motivasyonunu kaybettiği, devamsızlık yapmaya başladığı ve bu devamsızlığın da öğrenci başarısını olumsuz etkilediği söylenebilir. Öğrencilerin derslerde başarısız olacakları inancı öğrencilerin devamsızlık yapma olasılığını arttıran bir etkendir (Kadı, 2000). Bu gruptaki öğrencilerden bazılarının verdikleri yanıtlar aşağıda gösterilmiştir.

Öğrenci 5: Başarılı değilim. Çünkü okulu sevmiyorum (6. Sınıf, Erkek).

Öğrenci 7: Kendimi başarısız görüyorum. Çünkü derste çok şımarıyorum (6. Sinıf, Erkek).

Öğrenci 9: Başarısız görüyorum, çünkü dersime çalışmıyorum (6. Sınıf, Erkek).

b) Kendini başarılı olarak niteleme: Araştırma bulgularına göre kendini başarılı olarak gören öğrenciler sürekli devamsız öğrenciler olmayıp özellikle sağlık nedeniyle okula gelemeyen ve okulu, öğretmenleri dersleri seven ve okul çevresince yani arkadaşlarınca, öğretmenlerince sevildiğine inanan öğrencilerdir. Bu gruptaki öğrencilerden bazılarının verdikleri yanıtlar aşağıda gösterilmiştir. 
Öğrenci 11: Kendimi başarılı bir öğrenci olarak görüyorum. Çünkü derslerime çalışıyorum. Çünkü kitap okuyorum (7. Sınıf, Kız).

Öğrenci 17: Başarılı öğrenciyim, kendime inanıyorum (8. Sınıf, Erkek).

Öğrenci 19: Çalışırsam başaracağıma inanıyorum (8. Sınıf, Erkek).

Öğrenci 22: Başarılı bir öğrenciyim. Derslerime çalıştı̆̆ımı düşünüyorum (8. Sınıf, Erkek).

\subsection{Devamsızlık nedenleri}

Öğrencilerin devamsızlık yapma nedenlerine ilişkin verdikleri yanıtlardan elde edilen bulgulara göre öğrenciler; ailevi nedenler, kişisel nedenler, ve arkadaş çevresinden kaynaklı nedenler şeklinde 3 ana temaya ayrılmış ve bunlara ilişkin betimsel istatistikler Çizelge 3 'de verilmiştir.

Çizelge 3. Öğrencilerin Devamsızlık Nedenleri

\begin{tabular}{lccc}
\hline Faktörler & N & \% & Sıralama \\
\hline Ailevi Nedenler & 13 & 48,1 & 1 \\
Kişisel Nedenler & 11 & 40.8 & 2 \\
$\begin{array}{l}\text { Arkadaş Çevresinden } \\
\text { Kaynaklı Nedenler }\end{array}$ & 3 & 11.1 & 3 \\
Toplam & 27 & 100 &
\end{tabular}

Çizelge 3'e göre öğrenciler devamsızlık nedeni olarak (13 öğrenci \%48,1 ile) 1 . sırada ailevi nedenleri göstermişlerdir. Öğrenciler (11 öğrenci \%40,8 ile) 2. Sırada kişisel nedenleri, toplam 3 öğrenci de devamsızlıklarının nedeni olarak (\% 11,1 ile) arkadaş çevresini göstermişlerdir.

a) Aile Kaynaklı Nedenler: Öğrencilerin devamsızlık yapma nedenlerine ilişkin verdikleri cevaplardan elde edilen bulgulara göre nedenler "Ailenin İşe Gönderme Baskısı" ve "Ailenin Farklı Yerlerde Mevsimlik Çalışması," olmak üzere 2 alt temaya ayrılmıştır. Buna göre yapılan görüşmelerden 10 öğrenci velisinin çocuklarını okula göndermek yerine işe gönderdikleri bulgusu elde edilmiş̧tir. Türkiye'de yapılan araştırmalarda, mevsimlik tarım iş̧̧iliği yapan ailelerin çocuklarının okula uzun süreli devamsızlık yaptıkları ve okuldan diplomasız ayrıldıkları, okulu terk etmiş erkek çocukların aile bütçesine katkıda bulunacak işlerde çalıştıkları, kız çocukların ise daha çok evde kalarak küçük kardeşlerinin bakımını üstlendikleri, bulgularına ulaşılmıştır. (ERG, 2011).

Düzenli bir işte çalışmayıp yaşanılan çevrede bulunan tarla, bağ, bahçe işlerine gittiklerini ve çalışmaları için ailelerinden baskı gördüklerini anlatan bu öğrenciler eğer işe gitmezler ise okula gideceklerini ve okulu, öğretmenlerini sevdiklerini belirtmişlerdir. Bu gruptaki öğrencilerin genellikle 7. ve 8. Sınıf öğrencileri oldukları görülmektedir. Kadı'ya (2000) göre Ailelerin ekonomik olanaksızlıkları nedeniyle çocukların işgücünden yararlanması, ailenin çocuğuyla yakından ilgilenmemesi ve sorunlarını paylaşmaması, mevsimlik işlerde çalışan ailelerin çocuklarını da yanlarında çalıştırmak istemeleri, okul aile işbirliğinin sağlanamaması devamsızlığın temel nedenlerindendir. Bu gruptaki öğrencilerden bazılarının verdikleri yanıtlar aşağıda gösterilmiştir.

Öğrenci 10: Ailemin sağlık durumu çok iyi olmadığı için ben çalışıyorum 
(7. Sinıf, Kiz).

Öğrenci 15: Hayvanlara bakmak zorunda olduğumdan dolayı devamsızlık yapiyorum (7. Sinif, Erkek).

Öğrenci 18: Kendi ailem işe gönderiyor öğretmenim (8. Sınıf, Erkek).

Öğrenci 19: Çalışıyorum, maddi durumumuz sakat ve çalışmaya mecburum (8. Sinif, Erkek).

Öğrenci 20: Anne-babam işe git diyor (8. Sınıf, Erkek).

Devamsızlık nedeni olarak aile faktörünü söyleyen öğrencilerden 3'ü ailenin yaşadığı çevrede iş bulamaması veya geçinememesi nedeniyle zaman zaman başka yerlere taşındıklarını ve taşınılan yerde okula gönderilmemeleri sonucu devamsızlık yaptıklarını ileri sürmüşlerdir. Bu gruptaki öğrencilerden bazılarının verdikleri yanıtlar aşağıda gösterilmiştir.

Öğrenci 2: Davutlara taşınmamız nedeniyle devamsızlık yaptım. Babam orada okula göndermedi bizi (6. Sınıf, Kız)

Öğrenci 11: Davutlara taşındığımız için devamsızlık yaptım. (6. Sınıf, Kız).

Öğrenci 13: İncir toplamaya gittiğimiz için. (7. Sınıf, Kız).

b) Öğrencinin kendisinden kaynaklanan nedenler: Öğrencilerin devamsızlıklarının nedeni olarak 2. sırada gösterdikleri kendilerinden kaynaklanan nedenlere göre, 8 öğrenci kendi istekleri ve kendi kararları sonucu okula gelmediklerini ifade etmişlerdir. Bu gruptaki öğrenciler okulu ve dersleri sevmedikleri, okulda çok zorlandıkları, okulda canlarının çok sıkıldığı ve okulun hiç de eğlenceli bir yer olmadığını ifade ettikleri, aileleri okul terkine karşı çıksa bile devamsızlık yaptıkları ve okula gelmemek için büyük bir direnç gösterdikleri görülmektedir. Bu gruptaki 3 öğrenci devamsızlık nedenlerini sağlık problemleri olarak ifade etmişlerdir. Öğrencilerin kendisiyle ilgili bir sağlık problemi yaşaması ya da ailesinden birinin sağlı problemi yaşaması öğrencinin okula devamını etkilemektedir. İlköğretim düzeyinde yapılan bazı araştırmalarda, sağlık problemlerinin devamsızlığa neden olan en önemli etkenlerden biri olduğu anlaşılmıştır (Kadı, 2000; Yıldız, 2011). Sarı ve Cenksevenin (2008) yapmış oldukları bir çalışmada ise, öğrencilerin kendilerinden kaynaklanan en önemli devamsızlık nedenleri arasında yaşamakta oldukları herhangi bir hastalık, dersleriyle ilgili sınavlardan düşük not alma korkusu gibi etkenler yer aldığ 1 bulgusuna ulaşılmıştır. Öğrencilerin verdikleri yanıtların bazıları aşağıda gösterilmiştir.

Öğrenci 3: Kendim okula gelmek istemiyorum. Okulu sevmiyorum (6. Sınıf, Kız).

Öğrenci 7: Kendim istiyorum. Çünkü okulda çok canım sıkıldığı için (6. Sınıf, Erkek).

Öğrenci 14: Kendim istemiyorum (7. Sinıf, Erkek).

Öğrenci 4: Çok hasta oluyorum. Doktora gidiyorum. Onun haricinde okula hep geliyorum (6. Sinif, Kiz).

Öğrenci 27: Bazen hasta olduğumdan okula gelemiyorum (8. Sınıf, Kız).

c) Arkadaş çevresinden kaynaklı nedenler: Araştırmaya katılan 3 öğrenci arkadaşlarına uydukları için okula gelmediklerini, arkadaşlarıyla çeşitli etkinlikler yapmanın okuldan daha eğlenceli olduğunu düşündükleri için devamsızlık yaptıklarını belirtmişlerdir. Özellikle okul arkadaşlarından daha çok yaşadıkları mahallelerdeki arkadaşlarına uyduklarını belirten öğrenciler arkadaş çevrelerinin değişmesi halinde daha az devamsızlık yapacaklarını söylemişlerdir. Bu gruptaki öğrencilerin sorulara verdikleri yanıtlardan bazıları aşağıda belirtilmiştir.

Öğrenci 24: Arkadaş çevremle beraber olmak için kaçıyorum okuldan (8. Sınıf, Erkek). 
Öğrenci 25: Arkadaş çevremin etkisiyle okula gelmiyorum (8. Sınıf, Erkek).

\subsection{Devamsızlı̆̆a Ailede Gösterilen Tepkiler}

Öğrencilerin devamsızlık yapmalarına karşın anne ve babalarının gösterdiği tepkiler öğrenci ifadelerine göre değerlendirilmiş ve alınan yanıtlar doğrultusunda "Tepkisizlik" ve "Psikolojik tepki (Kızma davranışı)" alt temalarına ulaşılmıştır. Bu temalarla ilgili bulgular aşağıda gösterilmiştir.

Çizelge 4. Devamsızlı̆̆a Annenin Gösterdiği Tepki.

\begin{tabular}{llllc}
\hline Ana Tema & Alt Temalar & N & \% & Siralama \\
\hline \multirow{3}{*}{ Annenin tepkisi } & Tepkisizlik & 14 & 51,9 & 1 \\
\cline { 2 - 5 } & Psikolojik tepki & 13 & 48,1 & 2 \\
\cline { 2 - 5 } & Toplam & 27 & 100 &
\end{tabular}

a) Annenin gösterdiği tepki: Çizelge 4'e bakılarak araştırmaya katılan öğrencilerin annelerinin 14'ünün (\% 51,9) öğrencilerin devamsızlık yaptığını bilmesine karşın çocuklarına karşı hiçbir tepkide bulunmadıkları ve çocuklarının okula devamsızlığını azaltmak için herhangi bir çaba göstermedikleri görülmektedir. Öğrenci annelerinin 13'ü (\% 48,1) ise çocuklarına kızma davranışlarında bulunmaktadırlar. Bu gruptaki öğrencilerin sorulara verdikleri yanıtlardan bazıları aşağıda belirtilmiştir.

Öğrenci 1: Hiç bir şey demiyorlar (5. Sınıf, Erkek).

Öğrenci 2: Tepkisi yok (6. Sınıf, Kız).

Öğrenci 3: Annem bağırıp kızıyor (6. Sınıf, Erkek).

Öğrenci 8: Kızar (6. Sinıf, Erkek).

b) Babanın gösterdiği tepki: Araştırmaya katılan öğrencilerin babalarının 15 ' $i(\% 55,6)$ çocuğunun devamsızlığına karşı herhangi bir tepki göstermemektedir. Öğrencilerin babalarından 12'si (\%44.4) çocuğuna psikolojik tepki göstermektedir. 12 öğrencinin babası, devamsızlıklarını öğrendikleri çocuklarına kızmışlar ve devamsızlık yapmamaları konusunda çocuklarını uyarmışlardır. Fakat bu veliler devamsızlık yapan çocuklarına fiziksel şiddet uygulamamışlardır.

Çizelge 5. Devamsızlı̆̆a Babanın Gösterdiği Tepki.

\begin{tabular}{llccc}
\hline Ana Tema & Alt Tema & N & \% & Sıralama \\
\hline \multirow{3}{*}{ Babanın tepkisi } & Tepkisizlik & 15 & 55,6 & 1 \\
& Psikolojik tepki & 12 & 44,4 & 2 \\
& Toplam & 27 & 100 & \\
\hline
\end{tabular}

Elde edilen bulgulara göre babaların anneye göre daha tepkisiz olmasının, babanın çocuklarının eğitim sorumluluğunu anneye bıraktığı, çocukların eğitimi ile uzaktan ilgilendiği anlamı 
çıkarılabilir. Bu gruptaki öğrencilerin verdikleri yanıtlardan bazıları aşağıda belirtilmiştir.

Öğrenci 2: Tepkisi yok (6. Sınıf, Kız).

Öğrenci 10: Tepki vermiyor (7. Sınıf, Kız).

Öğrenci 14: Babam kızıyor (7. Sınıf, Erkek).

Öğrenci 19: Bağırır, kızar (8. Sınıf, Erkek).

Çocuğun devamsızlık yapmasına tepki gösterilmemesi, yönlendirme yapılmaması öğrencinin istenmeyen bu davranışı pekiştirmesine neden olabileceği gibi, çocuğa psikolojik tepki (kızma v.b) vermenin de davranışta geçici bir düzelme sağlamakla birlikte kalıcı bir düzelme sağlamayacağı söylenebilir. Nitekim görüşme yapılan bazı öğrenciler bu tür psikolojik tepkilerden bir süre sonra tekrar okula devamsızlık yaptıklarını söylemişlerdir.

\subsection{Devamsızlı̆̆a okul yöneticilerinin tepkisi}

Devamsızlık konusunda okul yöneticilerinin gösterdiği tepkilere ilişkin olarak öğrencilerin verdikleri yanıtlardan elde edilen bulgular; "Karşılıklı konuşma (İletişim)" "Tepkisizlik" ve "Psikolojik tepki (Kızma davranışı)" şeklinde 3 ana temaya ayrılmış ve bunlara ilişkin betimsel istatistikler Çizelge 6' da verilmiştir.

Öğrencilerle yapılan görüşmelerden okul yöneticilerinin devamsız öğrencilerin 15'i ile (\%55.6) iletişim kurduğu, 7'si ile (\%25.9) hiç ilgilenilmediği ve bu öğrencilere herhangi bir tepkide bulunmadıkları anlaşılmıştır. Okul yöneticileri devamsızlık yaptığı için 5 öğrenciye psikolojik tepki (Kızma davranışı) göstermişlerdir.

Çizelge 6. Devamsızlığa Okul Yöneticisinin Gösterdiği Tepki.

\begin{tabular}{llccc}
\hline Ana Tema & Alt Tema & N & \% & Sıra \\
\hline & $\begin{array}{l}\text { Karşılıklı konuşma } \\
\text { (İletişim) }\end{array}$ & 15 & 55,6 & 1 \\
Yönetici Tepki & Tepkisizlik & 7 & 25,9 & 2 \\
Durumu & Psikolojik Tepki & 5 & 18,5 & 3 \\
& Toplam & 27 & 100 & \\
\hline
\end{tabular}

Öğrencilerin verdikleri yanıtlardan bazıları aşağıda gösterilmiştir.

Öğrenci 6: Bizimle konuştu ve sonra mahallemize geldi, ailemle de konuştu. Gönderin bu çocuğu okula dedi (6. Sinıf, Erkek).

Öğrenci 8: Uyarır, konuşur, okula gel der ve eve mektuplar gönderir (6. Sınıf, Erkek).

Öğrenci 9: Mahalleye geliyor annemle konuşuyor bizim okula gelmemizi İstiyor (7. Sinif, K1z).

Öğrenci 17: Devamsızlık yapmamı engellemeye çalışır. Benimle de ailemle de konuşur (8. Sinıf, Erkek).

Öğrenci 5: Hiçbir tepki vermediler (6. Sınıf, Erkek).

Öğrenci 9: Geç kağıdı almamı ister ve bana bağırır (6. Sınıf, Erkek). 


\subsection{Devamsızlığa öğretmenlerin tepkisi}

27 öğrenci ile yapılan görüşmelerden elde dilen bulgulara göre 18 öğrencinin $(\% 66,7)$ okula devamsızlı durumu ile hiçbir öğretmen ilgilenmemiştir. Okuldaki branş öğretmenlerinden Türkçe öğretmeni (4 öğrenci), Matematik öğretmeni (3 öğrenci) ve Görsel sanatlar öğretmeni (2 öğrenci) olmak üzere devamsızlık yapan toplam 9 öğrenci ile görüşmeler yapmışlardır. Araştırma kapsamında görüşme yapılan 18 öğrenci devamsızlıkları ile ilgili hiçbir öğretmenden herhangi bir tepki almadıklarını, kendilerine ilgi gösterilmediğini, herhangi bir iletişime geçilmediğini ve devamsızlıklarının öğretmenlerince önemsenmediğini belirtmişlerdir. Veenstra ve arkadaşlarının (2010), yapmış olduğu bir araştırmada; çocuğun aile ve öğretmenlerle olan iletişim eksikliği ile sosyal yönlendirme yetersizliğinin okula devamsızlığın bir nedeni olduğu belirtilmiştir. Bu gruptaki öğrencilerin sorulara verdikleri yanıtlardan bazıları aşağıda gösterilmiştir.

Öğrenci 2: Tepki göstermezler (6. Sinıf, Kız).

Öğrenci 5: Hiçbir öğretmenim tepki vermedi (6. Sınıf, Erkek).

Öğrenci 16: Bilmiyorum, hiçbir öğretmenim bir şey demedi (8. Sınıf, Erkek).

Öğrenci 1: Matematik öğretmenim bana destek oluyor, devamsızlık yaptığımda benimle konuşuyor (5. Sınıf, Erkek).

Öğrenci 12: Türkçe öğretmenim tepki gösteriyor, ilgileniyor (7. Sınıf, Kız).

\section{9. Ö̆̆rencilerin okula devam edebilme şartları}

Okula devam için öğrencilerin verdikleri yanıtlardan elde edilen bulgular; Ailenin okula gitmelerine izin vermesi, eğlenceli bir okul, sağlık problemlerinin çözülmesi ve arkadaş çevresinin değişmesi şeklinde sıralanmış ve bunlara ilişkin bilgiler Çizelge 7'de verilmiştir. Araştırmaya katılan devamsız öğrencilerin okula devam edebilmeleri için birinci sırada önemli gördükleri durum "Aile izni” dir. 13 öğrenci aileleri izin verirse okula devam edeceklerini belirtmişlerdir. Öğrencilerin devamsızlık yapmayı bırakma şartlarına ilişkin verdikleri yanıtlardan elde edilen bulgular doğrultusunda Aile ile ilgili nedenler ana temasında incelenen veriler; "İșe gönderilmeme" ve "ailenin farklı yerlerde mevsimlik çalışmak için taşınmaması" bölümlerine ayrılmıştır. Öğrencilerden 10 tanesi eğer aileleri kendilerini işe göndermezlerse okula devam edeceklerini, 3 ’ü ise ailenin iş bulmak için taşınmaması durumunda devamsızlık yapmayacaklarını belirtmişlerdir.

Çizelge 7. Okula Devamsızlık Yapmayı Bırakma Şartları

\begin{tabular}{llccc}
\hline Ana Tema & Alt Tema & N & \% & Sıralama \\
\hline & Aile izni & 13 & 48,1 & 1 \\
& Eğlence & 8 & 29,7 & 2 \\
Devamsızlı̆ı & Suğlıkta iyileşme & 3 & 11,1 & 3,5 \\
Şrakma & Arkadları ç̧evresinin değişmesi & 3 & 11,1 & 3,5 \\
& Toplam & 27 & 100 & \\
\hline
\end{tabular}

İkinci sırada öğrencilerin okulu eğlenceli bulması gelmektedir. 8 öğrenci eğer okulun sıkıc1 değil de eğlenceli olması halinde devamsızlığı bırakacaklarını ifade etmişlerdir. Bu öğrenciler eğitim 
ve öğretim saatleri içinde okuldan sıkıldıkları için internet kafelere giden, arkadaşlarıyla mahallelerinde veya farklı yerlerde zaman geçiren ve kendi istekleri ile okula gelmeyen çocuklardır. Gökşen ve arkadaşları (2009), çalışmalarında eğitim sistemi ve okul koşullarının kötülüğünün okulu terk etmeye neden olan etmenler arasında, ekonomik nedenlerin hemen ardindan, ikinci sırada olduğunu saptamışlardır. Okula aidiyet hissi, ders dışı faaliyetler, okulun fiziksel koşulları, öğretmen ve öğrenci ilişkileri çocukların okula devam etme kararları üzerinde etkili olmaktadır.

Üçüncü sırada 3 öğrenci eğer iyileşirlerse, hastalıkları tedavi olursa devamsızlık yapmayacaklarını ifade etmişlerdir. Bu gruptaki öğrenciler yetersiz beslenme, yaşadıkları yerlerin hijyenik olmaması gibi nedenlerle sık sık hastalanmakta ve doktora da rahatça gidip tedavi olamadıkları için hastalıkları uzun sürmekte ve bu nedenlerle devamsızlık yapmaktadırlar.

Dördüncü sırada 3 öğrenci arkadaş çevresinin değişmesi halinde devamsızlığı bırakacaklarını söylemişlerdir. Bu gruptaki öğrencilerin verdikleri yanıtlardan bazıları aşağıda gösterilmiştir.

Öğrenci 10: Ailemin sağlık durumu iyi olur ve çalışırlarsa ben okuluma gelmeye devam ederim (7. Sinif, Kiz).

Öğrenci 15: Hayvanlara bakmazsam gelirim (7. Sinıf, Erkek).

Öğrenci 18: Çalışmam gerekmediğinde devamsızlık yapmayı bırakırım (8. Sinif, Erkek).

Öğrenci 19: Maddi durumumuz düzelirse okula gelirim (8. Sınıf, Erkek).

Öğrenci 20: Ailemize iş olursa çalışmazsak geliriz (8. Sınıf, Erkek).

Öğrenci 2: Annemle babamın işi düzelirse okula sürekli gelirim (6. Sınıf, Kız).

Öğrenci 13: Anne babamın işi yüzünden gelemiyorum. Hep burada olsak devamsızlık yapmam (7. Sinıf, Kız).

Öğrenci 7: Okulda canım sıkılmazsa, okul zor gelmezse, eğlenceli olursa okula devamsızlık yapmam (6. Sinıf, Erkek).

Öğrenci 14: Okulu seversem, sıkılmazsam devamsızlık yapmayı bırakırım (7. Sinıf, Erkek).

Öğrenci 1: Hastalı̆̆ım geçince okula gelirim (5. Sınıf, Erkek).

Öğrenci 27:Okula devam edebilmem için sağlık problemlerimin olmaması gerekir (8. Sinıf, Kız).

Öğrenci 24: Arkadaşlarım değişirse, çalışkan, okula sürekli giden arkadaşlarım olursa ben de devamsızlık yapmam (8. Sınıf, Erkek).

\section{SONUÇ VE ÖNERILER}

Devamsızlık nedenleri cinsiyet bakımından değerlendirildiğinde erkek öğrencilerin kız öğrencilerden daha fazla devamsızlık yaptıkları anlaşılmıştır. Öğrencilerin yaşlarına bakarak devamsızlıkları değerlendirildiğinde, 14-yaş grubu öğrencilerin devamsızlık yapmada diğer yaş gruplarına göre daha önde olduğu görülmüştür.

Devamsızlıkların en önemli nedeninin “aileden kaynaklanan nedenler” (\% 48,1) olduğu, devamsızlıklar üzerinde en az etkili olan nedenin ise "arkadaş çevresi" ile öğrencilerin "sağlık problemleri" (\%11,1) olduğu anlaşılmıştır. Yapılan görüşmelere göre ön önemli devamsızlık nedeninin ailelerin çocuğu işe göndermelerinin ve farklı yerlerde mevsimlik çalışmak için taşınmasının olduğu ortaya çıkmıştır. Devamsızlık yapan öğrencilerden 16'sı bir işte çalışmaktadır. 
Çalışmadıklarını söyleyen 11 öğrencinin ise evde ev işleri yapmak, çocuk bakmak gibi işlerle uğraştıkları anlaşılmıştır. Bu duruma göre araştırma grubundaki devamsız öğrencilerin hemen hepsinin çalıştıkları söylenebilir.

Çalışma grubu içinde üç ve daha fazla kardeşi olan öğrenciler (23 kişi) çoğunluktadır. Devamsız öğrencilerin \% 81,5'nin anne babası birliktedir. Devamsız öğrencilerin anne ve babalarının eğitim düzeyleri düşüktür. Anne ve babanın birlikte olması öğrencinin okula devamsızlık yapmaması lehine bir durum yaratmamakla birlikte, anne ve babanın eğitim düzeyinin düşüklügünün devamsızlığa bir neden oluşturduğu söylenebilir. Devamsız öğrencilerin büyük çoğunluğu kendilerini başarısız birer öğrenci olarak görmektedirler. Bu öğrencilerin \% 59.2'si dersleri başaramayacakları önyargısına sahiptir.

Araştırma yapılan okulun bulunduğu çevrenin sosyo ekonomik düzeyi düşüktür. Bu bölgede yaşayan veliler çocukların okul yerine işe gitmelerini normal olarak görmektedirler. Önemli düzeyde devamsızlığa sahip öğrencilerin anne ve babalarının devamsızlığa karşı geliştirdikleri tepkiler incelendiğinde bu durumu önemsemeyenlerin ve sessiz kalanların oldukça fazla olduğu anlaşılmaktadır.

Okul idaresi devamsızlığa karşı genel olarak sözlü uyarıda bulunmaktadır. Öğretmenlerin büyük çoğunluğu devamsızlıklarla ilgili herhangi bir kaygı taşımamaktadır. Öğrencilerin devamsızlığı azaltmaya yönelik çözüm önerilerinin devamsızlık nedenleriyle bağlantılı olduğu görülmüsstür. Aileden kaynaklı sorunların ortadan kalkması, okul için aile izninin sağlanması, okul ortamının daha eğlenceli olması, sağlık problemlerinin çözümlenmesi ve arkadaş ortamının farklılaşması öğrenciler tarafından belirtilen devamsızlığı azaltacak çözüm önerileri arasında bulunmaktadır.

\section{TARTIŞMA}

Araştırma bulguları, öğrencilerin ailelerinden kaynaklanan özelliklerin, onların okula devamlarını, akademik başarılarını etkilediğini göstermektedir (Beler, 1990; Bilgin, 1990; Eastman, 1998; Eğitim Reformu Girişimi, 2009; Yavuzer, 1992; Yaylac1, 1999). Bu araştırmanın bulguları incelendiğinde de devamsızlığa yol açan en önemli etkenin aile kaynaklı nedenler olduğu görülmüştür. Ulusoy ve arkadaşlarına göre (2005), ailelerin çocuk yetiştirme biçimi ile ailelerin sosyal ve ekonomik durumu, aile içi ilişkiler ve aile içi şiddet, gencin etiketlenmesi, gencin ve ailesinin madde bağımlılığı, gencin hayatı yaşamaya değer bulmaması ve hayata ait düşüncelerinin katılığı, okula devamsızlığı beraberinde getirmektedir (Ulusoy ve ark. 2005). Araştırma bulguları incelendiğinde çalışma grubundaki öğrencilerin madde alışkanlığı olmadığ 1 ve ailelerinden fiziki şiddet görmedikleri ancak, ailenin sosyo ekonomik düzeyinin düşük olduğu ve bu durumun da devamsızlığın önemli bir nedeni olduğu ortaya çıkmıştır. Güler'in (2002) "Çocuk İşgücü ve Eğitim” konulu araştırmasından elde ettiği sonuçlara göre, ailedeki çocuk sayısının fazla olması ve gelir düşüklüğü ile ailenin eğitim düzeyinin düşüklüğü ve bilgi yoksunluğu, çocukları kaçınılmaz bir şekilde iş yaşamına girmeye zorlamaktadır. MEB Orta Öğretim Genel Müdürlüğünce yapılan bir araştırma raporuna göre (MEB 2013); Devamsızlıkları nedeni ile sınıf tekrarı yapan öğrencilerin babalarının çoğunluğu $(\% 59,4)$ ilköğretim mezunudur. Babaların \% 10,3'ü okuryazar, \% 4'ü okuryazar değildir. Annelerin ise, \% 55,2'si ilköğretim mezunu dur. \% 17,1'i okuryazar değil, \% 11,2'si okuryazar dır. Buna göre devamsızlı̆̆ın ve sınıf tekrarının ana nedeninin "ailenin eğitim durumu olduğunu" söylenebilir. 
Şahabettinoğlu ve arkadaşlarınca (2002) yapılan araştırmada, eğitimin özellikle kadın eğitiminin çocukların okula devamında son derece etkili olduğu, hane halkı reisinin kadın olmasının çocuğun okula gitme olasılığını artırdığı, ailenin eğitim düzeyi arttıkça çocukların çalışma hayatına erken atılma riskinin azaldığ 1 bulgularına ulaşılmıştır. Başka bir çalışmada (Gilmore, 1985). "eğitim düzeyi yüksek olan ailelerin çocuklarının daha az devamsızlık yaptığı ortaya konulmuştur." Araştırma bulguları incelendiğinde ortaya çıkan sonuç bu görüşlerle örtüşmektedir.

“Öğrencilerin kendisiyle ilgili bir sağlık problemi yaşaması ya da ailesinden birinin sağlık problemi yaşaması öğrencinin okula devamını etkilemektedir. İlköğretim düzeyinde yapılan bazı araştırmalarda, sağlık problemlerinin devamsızlığa neden olan en önemli etken olduğu saptanmıştır." (Kadı, 2000; Yıldız, 2011). Sağlık problemleri dışında da devamsızlık yapmaya neden olabilecek birçok faktör bulunmaktadır. Yıldız'a (2011) göre "merkezi sınavlara hazırlık bir devamsızlık nedeni" olarak gösterilmesine rağmen bu araştırma bulgularında devamsızlık yapmayla sınavlara hazırlık ilişkilendirilmediğinden bu görüşle ilgili bir bulgu elde edilmemiştir. Yapılan literatür taramasında okuldaki akademik başarısızlığı ele alan çalışmaların çok farklı faktörlere vurgu yaptığı görülmüştür. Kimi çalışmalar eğitime vurgu yaparak öğrencilerin okulda başarılı olması için eğitim ve öğretimin çocukların bireysel özelliklerine uygun yapılandırılması gereğinin altını çizerken, kimi çalışmalar eğitim ve öğretimin bazı çocuklara güç bazılarına ise kolay geldiği ve bu nedenle öğrencilerin bir kısmının daha en başta başarılı olamayacakları düşüncesiyle tembelliğe alıştıkları ve devamsızlık yaptıklarını belirtmektedir (Yavuzer, 2009). Dinçer ve Kolaşin (2009)'e göre, ortaöğretimde, öğrenci başarısında eşitsizliğin en önemli belirleyicileri, öğrencilerin sosyoekonomik ve akademik yetersizlikleridir. Ayrıca öğrencilerin kayıtlı oldukları program tipi de başarıyı etkileyen önemli bir etkendir. Araştırmada önemli düzeyde devamsızlığa sahip öğrencilerin kendilerini algılama biçimleriyle ilgili görüşleri incelendiğinde genel olarak olumsuz bir benlik algısına sahip oldukları, kendilerini başarısız olarak nitelendirdikleri anlaşılmıştır.

$\mathrm{Bu}$ araştırmada da bazı öğrenciler, öğretmenlerin devamsızlık yapmalarıyla ilgili kendileri ile herhangi bir diyoloğa girmediğini ifade etmişlerdir. Bu durum da, öğrencinin öğretmenine karş1 olumsuz duygular beslemesine sebep olmaktadır. Öğrencilerin sıkça bahsettiği bir diğer konu ise öğretmenlerin dersleri eğlenceli kılacak unsurlar kullanmamaları ve derslerin tekdüze geçmesidir. Bu yüzden, öğrenciler olumsuz bir şekilde etkilenmekte ve devamsızlık problemi yaşamaktadır." Okulların en önemli varlık nedenleri öğrencilerin eğitim gereksinimlerini karşılamak ve onlara güçlü oldukları alanlarda gelişme olanakları sunmaktır. Okulların bu işlevleri çoğu kez gerçekleştiremedikleri görülmektedir. Öğrenciler, kişisel gereksinimlerinin karşılandığ ve bunun çeşitli etkinlikler aracılığıyla devam ettirildiği ortamlarda bulunmak ister (Jones ve Jones, 1997). "Öğrencilerin grup dinamiğinin etkisiyle bir grup içerisine girebilmek, gruba ayak uydurmak ya da grupta söz sahibi olmak için devamsızlık yapabildikleri ileri sürülmektedir." (Arkonaç, 2001; Güney, 2000; Kağıtçıbaşı, 1998). Araştırmanın bulgularıyla bu görüş ise paralellik göstermektedir.

\section{6. ÖNERILER}

Öğrencilerin okulu benimsemeleri için eğitsel etkinlikler düzenlenebilir.

Okul yönetimleri demokratik, hoşgörülü ve esnek bir tutum oluşturup, öğrencilerin de görüşlerini alarak, onların istek ve beklentilerini uygun olan sınırlar içinde hayata geçirebilir.

Okul idaresi, Milli Eğitim Müdürlüklerinin de desteği ile okul devamsızlığını önlemek için projeler 
üretip, etkili bir okul politikası oluşturabilir.

Devamsızlık nedenlerinin ortaya çıkarılması amacı ile bu tür problemi olan öğrencilerle yüz yüze görüşmeler yapılabilir. Elde edilen bulgular ailelerle paylaşılıp, okul aile ilişkileri çok daha etkin hale getirilebilir.

Okulların sadece öğretimin gerçekleştirildiği merkezler olmaktan çıkarılıp, yetenek derslerine de gereken önemin verilmesi gerekmektedir.

Okullarda öğrenci velilerine çocuk psikolojisi ve davranışları, çocuk sağlığı ve ana baba eğitimi ve gerekli olan diğer konularda seminerler düzenlenebilir. Bu seminerlere katılım özendirilebilir.

\section{Kaynakça}

Altınkurt, Y. (2008). Öğrenci Devamsızlıklarının Nedenleri Ve Devamsızlığın Akademik Başarıya Olan Etkisi. Dumlupınar Üniversitesi Sosyal Bilimler $\quad$ Dergisi, 20, 129-142.

Arkonaç, S. (2001). Sosyal Psikoloji. İstanbul: Alfa yayıncılık.

Bakış, O., Levent, H., İnsel, A. ve Polat, S. (2009). Türkiye'de Eğitime Erişimin Belirleyicileri. İstanbul: Sabancı Üniversitesi İstanbul Politikalar Merkezi.

Beler, F. (1993). “Anne ve Babaların Çocuğun Okul Başarısına Yardım ve Katkıları." Yayımlanmamış yüksek lisans tezi, İnönü Üniversitesi Sosyal Bilimler Enstitüsü, Malatya.

Bilgin, M. (1990). "Ankara Merkez İlçelerindeki Ortaokullarda Okul ile Ailenin İşbirliği ve Sorunları." Yayımlanmamış doktora tezi, Ankara Üniversitesi Sosyal Bilimler Enstitüsü Eğitim Yönetimi ve Planlaması Bilim Dalı, Ankara.

Dinçer, M. A. ve Kolaşin, G. U. (2009). Türkiye’de Öğrenci Başarısında Eşitsizliğin Belirleyicileri. İstanbul: Sabancı Üniversitesi Karaköy İletişim Merkezi.

Eastman, G. (1998). Family involvement in education. Madison WI: Wisconsin Department of Education.

Eğitim Reformu Girişimi. (2009). Eğitimde Eşitlik Politika Analizi ve Öneriler. İstanbul: Sabanc1 Üniversitesi İstanbul Politikalar Merkezi.

ERG (Eğitim Reformu Girişimi) (2010). Eğitim İzleme Raporu 2009. İstanbul: ERG.

Gilmore, J. (1985). Improving the attendince of primary children by involving parents in their education. ERIC Document Number: ED 264941. 
Gökşen , F., Z. Cemalcılar ve C. F. Gürlesel (2009). Türkiye'de ilköğretim okullarında okulu terk ve izlenmesine yönelik politikalar. İstanbul: ERG.

Güler, E. Ç. (2002). Çocuk İşgücü ve Eğitim (ss. 223-234). Türkiye'de Çalışan Çocuklar Semineri, 29-31 Mayıs 2001 Ankara, T.C. Başbakanlık Devlet İstatistik Enstitüsü ve Uluslararası Çalışma Örgütü-ILO. Ankara: Devlet İstatistik Enstitüsü Matbaası.

Güney, S. (2000). Davranış Bilimleri. Ankara: Nobel yayıncılık.

Jerald, C.D. (2006) Identifying Potential Dropouts: Key Lessons For Building an Early Warning Data System. American Diploma Project Network.

Jones, V. \& Jones, L. S. (1997). Responsible classroom discipline: creating positive learning environments and solving problems. Boston: Allyn and Bacon.

Kadı, Z. (2000). “Adana ili merkezindeki ilköğretim okulu ögrrencilerinin sürekli devamsızlı nedenleri” (Yayımlanmamış yüksek lisans tezi). İnönü Üniversitesi, Malatya.

Kağıtçıbası, Ç. (1998). Yeni İnsan Ve Insanlar: Sosyal Psikolojiye Giriş. İstanbul: Evrim.

Kalafat, S. (2011). Öğrenci Gelişimi. K. Ersanlı \& E. Uzman, (Ed.), Eğitim Psikolojisi (2.Bask1) içinde (41-64). İstanbul: Lisans Yayıncılık.

Milli Eğitim Bakanlığı. (2006). Orta Öğretim Kurumları Sinıf Geçme ve Sinav Yönetmeliği (Rapor No. 26173). http://ogm.meb.gov.tr'den alınmıştır.

MEB Orta Öğretim Genel Müdürlüğü. (2013). Ortaöğretimde Sinıf Tekrarı, Okul Terk Sebepleri Ve Örgün Eğitim Dışında Kalan Çocuklar Politika Önerileri Raporu. Ankara, ISBN: 978-975-113809-5.

OECD. (2004). Learning for Tomorrow's. World First Results from PISA 2003. Paris: OECD.

OECD. (2013). PISA 2012 Results: Ready to Learn Students' Engagement, Drive and Self-Beliefs. Volume III. Paris: OECD.

Özbaş, M. (2010). İlköğretim okullarında öğrenci devamsılı̆ğının nedenleri. Ĕgitim ve Bilim,35 (156), 32-44.

Öztekin, Ö. (2013). “Lise öğrencilerinin devamsızlık nedenlerinin incelenmesi” (Yayınlanmamış Yüksek Lisans Tezi). Osmangazi Üniversitesi, Eskişehir.

Pehlivan, Z. (2006). "Resmi genel liselerde öğrenci devamsızlığı ve buna dönük okul yönetimi politikaları" (Ankara ili örneği)" (Yayımlanmamış doktora tezi). Ankara Üniversitesi, Ankara.

Sarı, M. ve Cenkseven, F. (2008). İlköğretim Öğrencilerinde Okul yaşam Kalitesi ve Benlik Kavramı. Uluslararasi İnsan Bilimleri Dergisi, 5(2):87-98.

Senemoğlu, N. (2005). Gelişim, ögrrenme ve öğretim: Kuramdan uygulamaya. Ankara: Gazi 
Kitabevi.

Şahabettinoğlu, M., Uyanık, D., Ayhan, N., Bakır, M.A. ve Ataöv, A. (2002). Çocukların Temel Eğitime Katılmasının Sosyoekonomik Engelleri ve Destekleri (ss. 235-255). Türkiye'de Çalışan Çocuklar Semineri, 29-31 Mayıs 2001 Ankara, T.C. Başbakanlık Devlet İstatistik Enstitüsü ve Uluslararası Çalışma Örgütü-ILO. Ankara: Devlet İstatistik Enstitüsü Matbaası.

Şimşek, H. (2011). Lise öğrencilerinde okulu bırakma eğilimi ve nedenleri. Eğitim Bilimleri Araştırmaları Dergisi, 1, (2), 27-47.

Ulusoy, M.D., Demir, N.Ö., Baran, A.G. (2005). Ebeveynlerin Çocuk Yetiştirme Biçimi ve Ergen Problemleri. Erişim: http://www.tebd.gazi.edu.tr/arsiv/2005 cilt3/sayi 3/367-386.pdf.

Veenstra, R. ; Lindenberg, S. ; Tinga, F.; Ormel, J. (2010). "Truancy in late elementary and early secondary education: The influence of social bonds and self-control - the TRAILS study". International Journal Of Behavioral Development, 34 (4), 302-310.

Yavuzer, H. (1992). Ana Baba Okulu, İstanbul: Remzi Kitabevi.

Yavuzer, H. (2009). Çocuk ve Suç. İstanbul: Remzi Kitabevi.

Yaylacı, A. F. (1990). “İlköğretim Okullarında Ailenin Okula Katılımı.” Yayımlanmamış yüksek lisans tezi, Ankara Üniversitesi Sosyal Bilimler Enstitüsü, Ankara.

Yıldız, M. (2011). "Illköğretim okulu öğrencilerinin devamsızlıknedenlerinin araştırılması" Yayımlanmamış yüksek lisans tezi). Ahi Evran Üniversitesi, Kırşehir.

Vural HOŞGÖR ̈̈R

Mustafa POLAT
Yrd. Doç. Dr. Muğla Sitkı Koçman Üniversitesi Eğitim Fakültesi

E-mail:vuralhosgorur@mu.edu.tr

Öğretmen, Aydın İl Milli Eğitim Müdürlüğü, E-mail: polatmustafa09@hotmail.com 